\title{
Identification of the key factors for success in the hotel sector
}

\author{
Antonio Alvarez-Ferrer (iD), Fernando Campa-Planas (iD), \\ Juan Pablo Gonzales-Bustos (D) \\ Universitat Rovira i Virgili (Spain) \\ antonio.alvarez@estudiants.urv.cat,fernando.campa@urv.cat,juanpablo.gonzales@hotmail.es
}

Received July, 2017

Accepted January, 2018

\begin{abstract}
Purpose: The aim of this work is to identify the key factors for success in the hotel sector. This objective is motivated by the importance of tourism in the Spanish economy, taking into account the fact that it represents $11.1 \%$ of the GDP and accounts for 13\% of all employment, with 2.49 million jobs, according to INE (Spanish National Statistics Bureau) data for 2015.

Design/methodology: A review of the literature has been carried out, which has provided references related to the hotel sector and different factors that impact it. The knowledge provided by the scientific community through the articles and texts consulted are reflected in this document and allow us to determine the existence of the key factors for success.

Findings: Considering the importance of the hotel sector in the Spanish economy, this study identifies the key factors in the different hotel establishments. However, the materialization of these factors provides and shows us which financial aspects, management systems and other more global aspects, such as longevity or location, enable the company to be successful in the hotel sector.
\end{abstract}

Originality/value: Based on the literature reviewed, a list of key factors for success in the hotel sector was composed. This also revealed a lack of similar studies on this topic.

Keywords: Hotel sector, Key factors, Profitability, Literature review

Jel Codes: Z33, M10

\section{Introduction}

The research proposed in this work is to review the literature to find and specify the key factors for success in the hotel sector. It must be kept in mind that success will be related to profitability, among other factors, which enables us to observe whether a company is sustainable over time.

A hotel located in an urban setting in an internationally very well-known tourist area (for example, Barcelona), with many customers year-round, is not the same as a hotel located in a non-urban setting, but one that is also touristic (i.e., located on a beach), such as Salou in Costa Dorada. In this second case, seasonality has a direct effect on its results and the profitability of the company. The same case occurs with an entire list of factors that can have a direct effect on profitability. 
An in-depth understanding of why one company is more profitable than another, learning to determine when a company can be considered to have a good economic situation or, on the contrary, it needs to modify and correct erroneous strategies that can force it out of the market due to the lack of profitability, are crucial aspects for all business management. The analysis of the hotel sector is very complex, due to its diversity and low levels of homogeneity, which requires us to take into consideration the different tourist areas, urban and non-urban establishments, the importance of companies according to their volume in terms of sales, assets or employees, the number of rooms, etc.

\section{The hotel sector}

Barrado and Galiana (2006) state that the development of tourism in Spain began with the economic openness of the 1960s and ended in 1974, a stage when the Spanish economy was favored by international economic development, thanks to low energy prices, cheap labor and currencies provided by emigrants and tourists. An explosion in mass tourism occurred that provided positive economic benefits, but that also had a detrimental effect, due to disastrous environmental and territorial management, as the result of speculative processes involving land, urbanization and construction.

It is after the 1990s and with the use of the Internet that tourism is able to reach a larger number of users. The Internet enables companies and public institutions to promote themselves, and facilitates access by the potential demand to obtain more and more varied information about the great diversity of tourist destinations (Vacas \& Landeta, 2009). In this era, the product begins to diversify and the quality offered to visitors improves, and the entire tourism activity is developed and planned in an organized manner to prevent the errors of past decades. Furthermore, an attempt is made to break away from the strong seasonality triggered by the sun and beach, which results in an excessive demand during three months of the year. While met, this demand implies the use of a large quantity of very concentrated resources and poor sustainability on the part of the system.

The main tourist attraction in Spain has been the price-quality ratio, its climate and beaches. These attractions have now been complemented with a vast offering of cultural, natural, wine and culinary and leisure options. We have the option of seeing monuments and museums like the Prado in Madrid; visiting Doñana National Park in Andalusia; tasting the best wines in Priorat or La Rioja; eating in the world's best restaurants, considering that Spain has 182 accredited restaurants in the Michelin Guide for 2016, or enjoying one of the best theme parks in Europe: Port Aventura in Vilaseca-Salou.

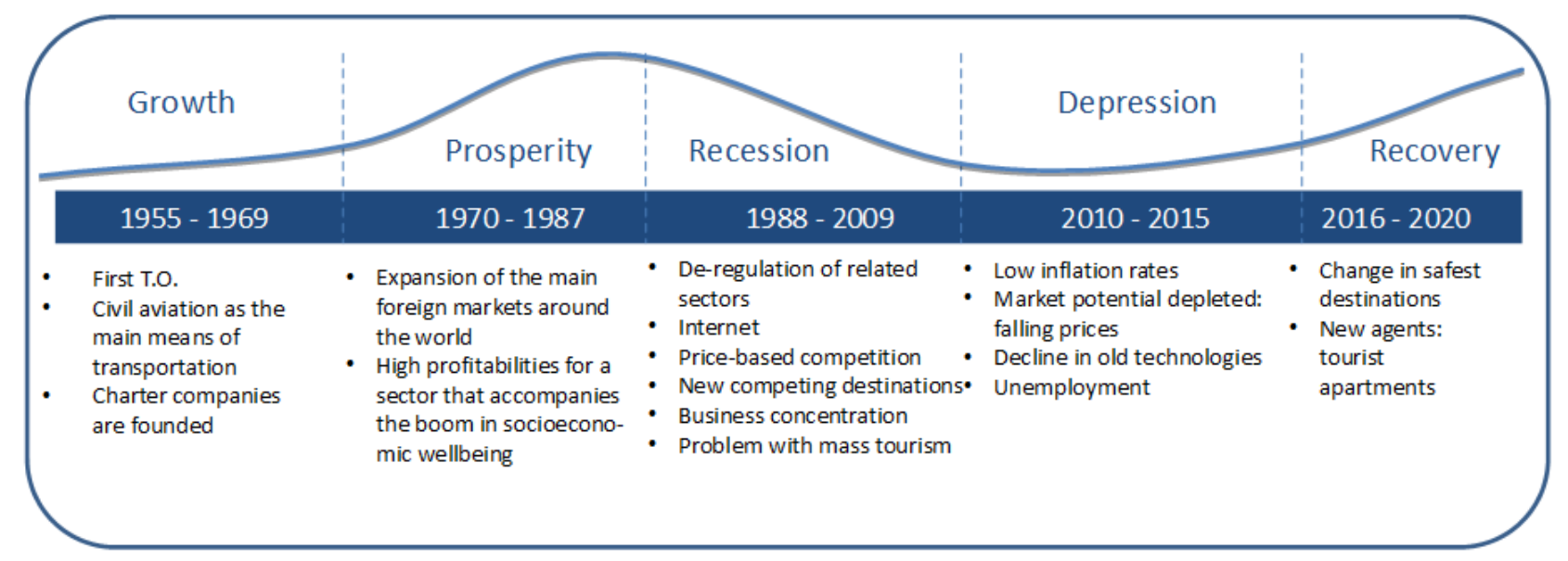

Figure 1. Stages in the tourism sector in Spain (own adaptation from the "National and Comprehensive Tourism Plan (PNIT) 2012-2015, Ministry of Industry, Energy and Tourism”)

Figure 1 shows the different stages of the tourism sector from the 1960s to present. It is clear to see that we are in difficult times, economically speaking, and that there is also a demographic change in European society, as the baby boomer generation reaches retirement age, starting in 2015. There is a noticeable reduction in demand in 
Western Europe, due to a decline in activity, which means a decrease in the income of the tourists who come to Spain. The excess offer in the market is accompanied by the disappearance of less efficient and less profitable companies as the result of the great competition that exists and the breaking of the value chain in which the tourist is at the center of the tourism business (National and Comprehensive Tourism Plan 2012-2015).

It can also be stated that it would seem that we can consider the depression of the 2010-2015 period of Figure 1 to be over, and the industry has once again entered a new spring. The fact is that the sector is recovering, as can be seen in Figure 2, which shows that never in the history of this country have so many millions of tourists visited us in a single year.

Authors such as Álvarez, Andrade, Caramés, Gomis, Leira and Rego (2008) believe that the entire tourism sector needs to be reassessed, based on innovation focused on tourists themselves. This will involve new business management models, new communications formats and the quest for client wellbeing in the widest sense, in particular with attention to health and his or her relation to the environment. Those tourist destinations that do not consider this new situation and do not know how to adapt to this new reality will gradually lose their market position. It is also true that the disappearance of the middle class reduces the number of people who have the economic capacity to travel, and so an increase in the number of tourists will not always go hand in hand with improved profits, but it will be accompanied by an increase in the overall income (Castelltort, 2006).

Tourism activity accounted for a total of $12.1 \%$ of the GDP in 2002, according to INE data. This figure has yet to be exceeded, taking into account the economic downturn Spain has suffered in the last decade. What is important is that in spite of the crisis and the downturn in sectors such as the industrial and construction sector, tourism can be considered to be one of the sectors driving the recovery (Figuerola, 2011).

We can see in Table 1 how, in spite of the current crisis, the tourism sector is one of the cornerstones maintaining employment, because not only does it not shrink like most other sectors, it actually increases its relative weight in the Spanish economy.

\begin{tabular}{cccc}
\hline Year & Total emploved & Emploved in the tourism sector & $\%$ tourism of the total \\
\hline $\mathbf{2 0 0 5}$ & $18,312,322$ & $1,799,356$ & $9,61 \%$ \\
$\mathbf{2 0 0 6}$ & $18,925,869$ & $1,846,460$ & $9,79 \%$ \\
$\mathbf{2 0 0 7}$ & $19,372,675$ & $1,937,209$ & $10,00 \%$ \\
$\mathbf{2 0 0 8}$ & $18,531,264$ & $1,999,557$ & $10,57 \%$ \\
$\mathbf{2 0 0 9}$ & $17,803,839$ & $1,917,405$ & $10,77 \%$ \\
$\mathbf{2 0 1 0}$ & $17,584,982$ & $1,932,224$ & $10,99 \%$ \\
$\mathbf{2 0 1 1}$ & $17,229,922$ & $1,948,374$ & $11,31 \%$ \\
$\mathbf{2 0 1 2}$ & $16,442,681$ & $1,934,542$ & $11,77 \%$ \\
$\mathbf{2 0 1 3}$ & $16,357,640$ & $1,936,225$ & $11,84 \%$ \\
$\mathbf{2 0 1 4}$ & $16,775,214$ & $2,001,448$ & $11,93 \%$ \\
$\mathbf{2 0 1 5}$ & $17,308,400$ & $2,093,334$ & $12,09 \%$ \\
$\mathbf{2 0 1 6}$ & $17,849,054$ & $2,193,730$ & $12,29 \%$ \\
\hline
\end{tabular}

Table 1. Employment from the tourism sector versus total employment in Spain (Spanish Government Ministry of Labor and Social Security, 2017)

Table 1 and Figure 2 reveal some important information: during the 2009-2016 period, the number of tourists has increased by $45.6 \%$, while the increase in workers employed in the same period only grew by $14.4 \%$. This information reflects that the hotel sector has managed to increase productivity at high levels. 


\section{Foreign tourists arriving in Spain}

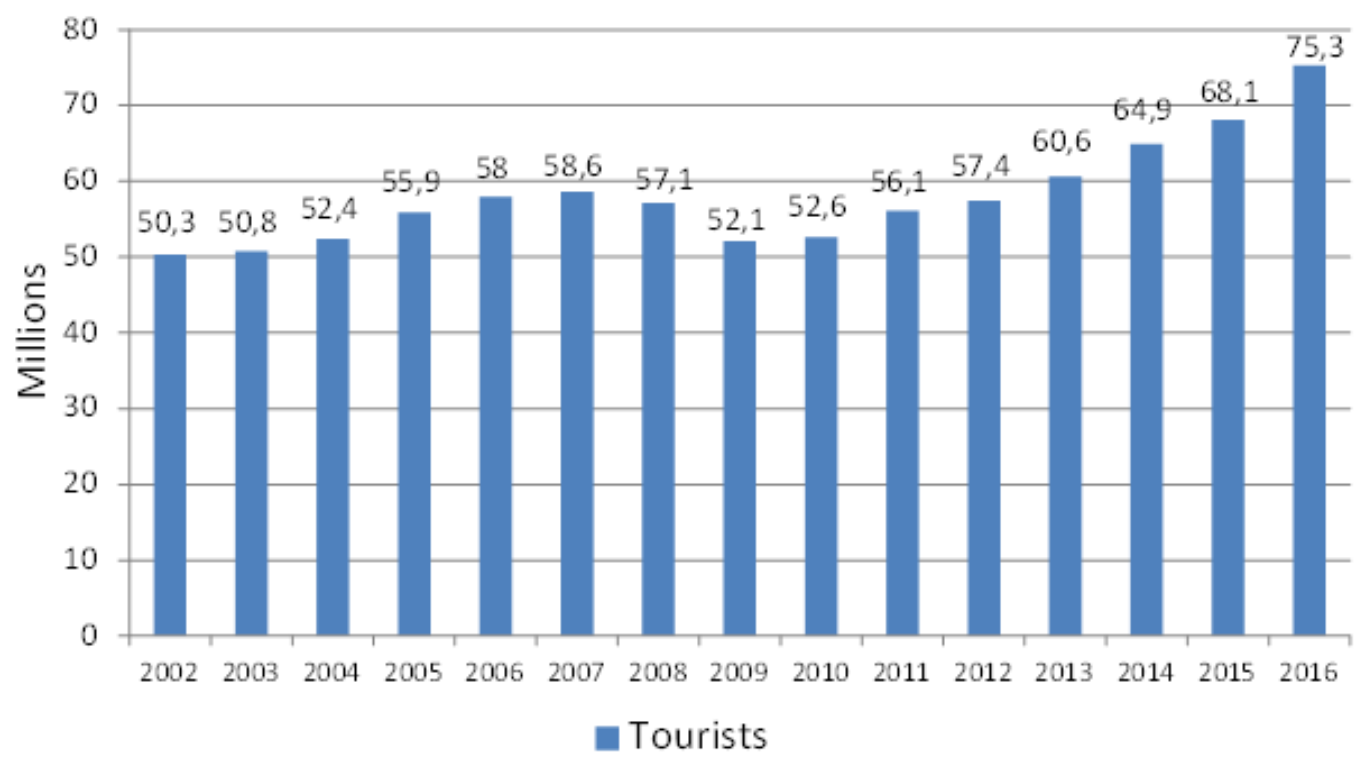

Figure 2. Millions of tourists in Spain (according to the INE and the Ministry of Energy, Tourism and Digital Agenda)

According to information published by the Minister of Energy, Tourism and Digital Agenda, Álvaro Nadal, Spain received a total of 75.3 million tourists in 2016, almost $10 \%$ more than the previous year, and set a new record for visitors (see Figure 2). Spain is currently the third top tourist destination in the world, only surpassed by France and the United States. It contributes around 11\% of the country's GDP, with record expenditures by tourists, and is one of the main job creators. In fact, both the service sector and the tourism sector, along with exports, are the cornerstones that are pushing the economy towards the end of the crisis (Ministry of Energy, Tourism and Digital Agenda, 2017).

\section{Review of the literature}

The methodology used in this study consisted of a systematic literature review, using the Scopus bibliographic database between the years 1963 and 2016. This database offers a broad vision of international academic articles, along with a large base of abstracts and citations.

\section{Documents by year}



Figure 3. Published documents related to profitability in the hotel sector (according to SCOPUS, during the period 1963 - 2016) 
Research was conducted using selected key words to identify the bibliography. These were: economic performance/profitability and hotel/lodging/accommodations/hospitality. Figure 3 shows, by year, the documents published during this period that demonstrate the growing interest in this topic. After 2000, the graph reveals a very sharp increase in the articles published by the different journals, the most productive of which are reflected in Figure 4.

\section{Documents by publication}

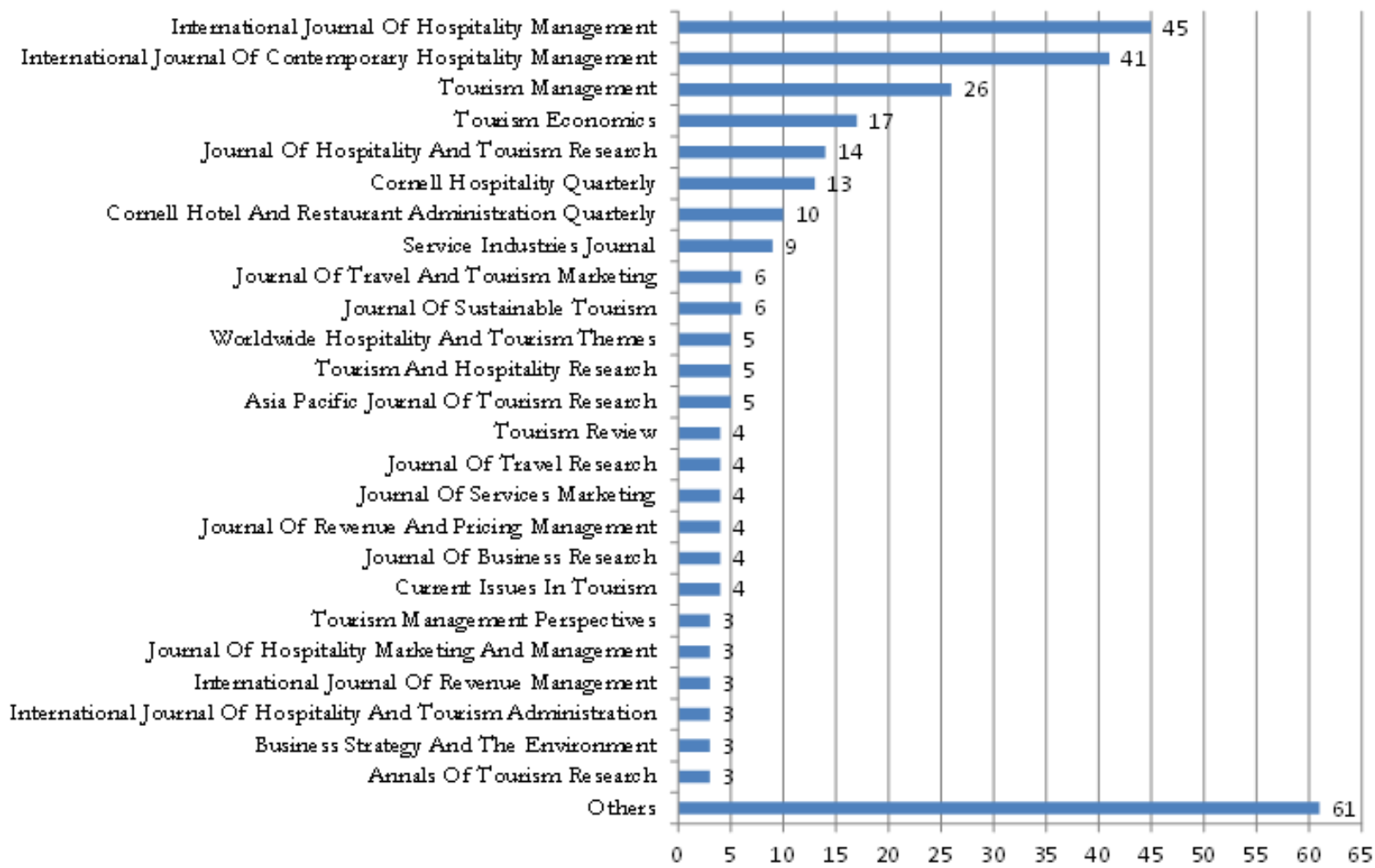

Figure 4. Journals that have published more than 3 articles related to profitability in the hotel sector (according to SCOPUS, during the period $1963-2016)$

The results of the research conducted are shown in Table 2, where it can be seen that a total of 11 factors have been identified that, according to the different authors, have a direct effect on management in the hotel sector. These factors will be analyzed individually in Section 4, where details are provided of the arguments given by the authors for the reason why they affect the organizations. 


\begin{tabular}{|c|c|}
\hline KEY FACTORS & AUTHOR \\
\hline Indebtedness & $\begin{array}{l}\text { AECA, 2002; Sánchez \& García, 2003; Acedo, Ayala \& Rodríguez, 2005; Aragón \& Rubio, } \\
\text { 2005; Palacín \& Ramírez, 2011; Monterrey \& Sánchez, 2011; González \& Jareño, } 2014 .\end{array}$ \\
\hline Size & $\begin{array}{l}\text { García, 1976; Maravall, 1976; Soler, 1977; Suárez, 1977; Donsimoni \& Leoz, 1980; Maravall, } \\
\text { 1981; Bueno \& Lamothe, 1983; Lafuente \& Salas, 1983; Arraiza \& Lafuente, 1984; Lafuente, } \\
\text { Salas \& Perez, 1985; Berges \& Soria, 1987; Lafuente \& Yagüe, 1989; Rodríguez, 1989; } \\
\text { Antón, Cuadrado \& Rodríguez, 1990; Fariñas et al., 1992; Huergo, 1992; Llorens, 1992; } \\
\text { Galvé \& Salas, 1993; Ocaña, Salas \& Valles, 1994; Salas, 1994; Ferruz \& González, 1994; } \\
\text { Fernández \& Gil, 1995; Illueca \& Pastor, 1996; Galán \& Vecino, 1997; González, 1997; } \\
\text { Maroto, 1993, 1996, 1998; Calvo, García \& Arques, 2000; González, Hernández \& } \\
\text { Rodríguez, 2000; Sánchez \& Bernabé, 2000; Andrés, 2000; AECA, 2002; Sánchez \& García, } \\
\text { 2003; Acedo et al., 2005; Aragón \& Rubio, 2005; Monterrey \& Sánchez, 2011; Hernández, } \\
\text { Campa \& Sánchez, 2012; Kasim, Dzakiria \& Ahmad, 2016; Andreu, Claver \& Quer, } 2017 .\end{array}$ \\
\hline Margin and asset rotation & $\begin{array}{l}\text { Sánchez, 1994; Sánchez \& García, 2003; Martorell \& Mulet, 2009; Lee, Capella, Taylor, Luo, } \\
\text { \& Gabler, } 2014 .\end{array}$ \\
\hline Operating leverage & $\begin{array}{l}\text { Mascareñas, 2001; Vázquez, 2001; Aranda \& Diéguez, 2006; Cheng, Liao, Xu, Hua \& Dai, } \\
\text { 2015; Yang, Albaity \& Hassan, } 2015 .\end{array}$ \\
\hline $\begin{array}{l}\text { Management system } \\
\text { (property) }\end{array}$ & $\begin{array}{l}\text { Caves, 1974; Brickley \& Dark, 1987; Milogrom \& Roberts, 1992; Holmströn \& Milgrom, } \\
\text { 1994; Holmström, 1999; AECA, 2002; Calderón, 2002; Ramón, 2002a; Pla \& León, 2004; } \\
\text { Newell \& Seabrook, 2006; Fernández \& González, 2006; Casamitjana, 2008; Fernández \& } \\
\text { González, 2008; Pereira, Claver \& Molina, 2011; Amat \& Campa, 2011; Ivanova \& Ivanov, } \\
\text { 2015; Hodari, Turner \& Sturman, } 2017 .\end{array}$ \\
\hline $\begin{array}{l}\text { Quality management } \\
\text { system }\end{array}$ & $\begin{array}{l}\text { Birdir \& Pearson, 1998; Nield \& Kozak, 1999; AECA, 2002; Nicolau \& Sellers, 2003; Chow, } \\
\text { Goh \& Wan, 2003; Aragón \& Rubio, 2005; Casadesús \& Karapetrovic, 2005; Gandara, Fraiz } \\
\text { \& Alén, 2007; Lee, To \& Yu, 2009; Martínez, Choi, Martínez \& Martínez, 2009; Nicolau \& } \\
\text { Sellers, 2010; Crick \& Spencer, 2011; Lo, Yeung \& Cheng, 2011; Pereira et al., 2011; Rubio, } \\
\text { Alonso \& Rodríguez, 2011; Tari \& Pereira, 2012; Alonso, Rodríguez \& Rubio, 2012; } \\
\text { Ladhari, 2012; Mokhtar \& Muda, 2012; Molina-Azorín, Jose Tari \& Pereira-Moliner, 2015; } \\
\text { Llach, Del Mar Alonso-Almeida \& Marti, 2016; Arbelo-Pérez, Arbelo \& Perez-Gomez, } \\
\text { 2017. }\end{array}$ \\
\hline $\begin{array}{l}\text { Environmental } \\
\text { management system }\end{array}$ & $\begin{array}{l}\text { Häversjö, 2000; Heras, Dick \& Casadesús, 2002; Martorell \& Mulet, 2009; Claver, Pereira, } \\
\text { Molina \& Tarí, 2010; Pereira et al., 2011; NH Hoteles, 2012; Segarra, Peiró, Verma \& Miret, } \\
\text { 2012; Molina-Azorín et al., 2015; Abdel-Maksoud Kamel \& Elbanna, 2016. }\end{array}$ \\
\hline $\begin{array}{l}\text { Corporate social } \\
\text { responsibility }\end{array}$ & $\begin{array}{l}\text { Friedman, 1970; McWilliams \& Siegel, 1997; Libro Verde RSC-UE, 2001; Jensen, 2002; } \\
\text { Small \& Graff Zivin, 2002; Callado \& Utero, 2005; Barnett \& Salomon, 2006; Toro, 2006; } \\
\text { García \& Yaiza, 2007; Moneva, Rivera \& Muñoz, 2007; Calveras \& Ganuza, 2008; Aras, } \\
\text { Aybars \& Kutlu, 2010; Acero \& Nuria, 2012; Benavides-Velasco, Quintana-Garcia \& } \\
\text { Marchante-Lara, 2014; García \& Del Bosque, 2015; Dinu \& Nistorescu, 2015; Medrado \& } \\
\text { Jackson, 2016; Kim, Rhou, Uysal \& Kwon, 2017. }\end{array}$ \\
\hline Yield Management & $\begin{array}{l}\text { Orkin, 1988; Rowe, 1989; Kimes, 1989; Smith, Leimkuhler \& Darrow, 1992; Lieberman, } \\
\text { 1993; González \& Sule, 1994; Goymur \& Donaghy, 1995; Lewis \& Shoemaker, 1997; Cook, } \\
\text { 1998; Chávez \& Ruíz, 2005; Jones, 2000; Marchionna, 2005; AECA, 2005; Campa, 2007; } \\
\text { Talón, González \& Segovia, 2012; Guha, 2016; Cetin, Demirciftci \& Bilgihan, } 2016 .\end{array}$ \\
\hline Longevity & $\begin{array}{l}\text { Brüderl \& Schüssler, 1990; AECA, 2002; Sánchez \& García, 2003; Taymaz \& Köksal, 2006; } \\
\text { López \& Vázquez, 2007; Carvell, Canina \& Sturman, 2015; Ben Aissa \& Goaied, 2016; } \\
\text { Sánchez-Medina, Díaz-Pichardo \& Cruz-Bautista, 2016. }\end{array}$ \\
\hline Location and position & $\begin{array}{l}\text { González, Correa, Hernández, Hernández \& Rodríguez, 1998; González et al., 2000; Roubi, } \\
\text { 2004; Smolyaninova, 2007; Pereira et al., 2011; Lockyer, 2013; De Jorge \& Suárez, 2014; Lee, } \\
\text { 2015; Kalnins, 2016. }\end{array}$ \\
\hline
\end{tabular}

Table 2. Factors affecting profitability 


\section{Results}

\subsection{Key factors}

As shown in Table 2, we will now explain the key factors that have been identified in the literature review. To facilitate their study, the factors have been classified in three groups, as can be seen in Table 3 and is explained below:

- We understand financial factors to be all those aspects that are associated with the financial analysis of a company and that have to do with investments, its financial structure and its results.

- Management factors refer to all the systems that companies have available to manage themselves in the most efficient way possible and that make it possible to obtain maximum performance. In our case, this includes aspects that are characteristic of, but not exclusive to, the hotel sector, such as Yield Management.

- Finally, we will find more generic aspects that all play a part. While not decisive in and of themselves, they become so in conjunction with the rest of the factors and they do condition it.

\begin{tabular}{|l|l|l|}
\hline FINANCIAL & MANAGEMENT & GENERIC \\
\hline Indebtedness & Management system (property) & Longevity \\
\hline Size (assets, sales, employees) & Quality management system & Location and position \\
\hline Margin and asset turnover & Environmental management system & \\
\hline Operating leverage & Corporate social responsibility & \\
\hline & Yield Management & \\
\hline
\end{tabular}

Table 3. Classification of the factors that can affect profitability (based on Table 2)

\subsubsection{Indebtedness}

Acedo et al. (2005) state that indebtedness is related to difficulties a company can have in accessing sources of financing. Small businesses and microenterprises have more difficulties than medium-sized and large businesses, and are required to offer extra guarantees, including personal guarantees, that medium and large companies are not required to provide.

Indebtedness has a greater incidence in small and medium-sized companies than in large ones. Companies of limited size, such as small businesses and microenterprises, have a greater level of indebtedness than mediumsized and large companies. The power of negotiation a small business can have as compared to a large one conditions its access to financing, and thus the effect of the company's size on the level of indebtedness would seem to be unquestionable (Aragón \& Rubio, 2005; Palacín \& Ramírez, 2011).

Palacín and Ramírez (2011) argue that the profitability variable contributes significantly to the indebtedness ratio. As their level of profitability increases, they use less debt, because they use greater quantities of internallygenerated resources to finance new investment projects. The financing decisions of SMEs differ from those made by large companies. Among the most prominent differences are:

- Greater informational opacity, and thus greater problems associated with asymmetrical information between managers and investors.

- Greater levels of risk.

- Insolvency costs that are greater than those of larger companies.

- Overlapping of the figures of owner and manager. 
- Low level of diversification of the owner's asset portfolio.

Monterrey and Sánchez (2011) describe a negative relationship between a company's indebtedness and persistence, in such a way that the profitability is less persistent in the companies with the greatest indebtedness. In this way, we can state that the companies with the highest levels of indebtedness are less likely to achieve sufficient profitability over time.

\subsubsection{Size}

There is no clear consensus on the influence of the size of a company. Monterrey and Sánchez (2011) empirically show that the size of a company has a positive relationship with persistence, in such a way that the profitability is more persistent in larger companies. There is also a group that defends the idea that the influence that the size of the company can have on its profitability will depend on the sector in which the organization operates (Maravall, 1976; Andrés, 2000; Sánchez \& García, 2003). With reference to the sector, González et al. (2000) also believe that the sector has greater importance than the size of the company when it comes to assessing economic profitability.

To determine the size, we must consider important aspects that have an influence, such as assets, sales and the number of employees. The specific classification of companies according to their size can be made according to the criteria established in the legal regulations on both a Spanish level (General Accounting Plan) and a European level (Recommendation of the European Commission 96/280, EC of 30 April).

\subsubsection{Margin and asset turnover}

According to Sánchez (1994), these two variables determine the economic profitability. In a study of 191 companies in 12 different sectors, he concluded that we can find companies that operate in very competitive markets and that, while operating in sectors with high capital intensity, earn greater margins, but with very low rotations. On the other hand, we will find others that achieve their economic profitability with high rotations that make up for smaller margins. Within each sector, the companies that obtain greater margins are also the best in terms of economic profitability, as long as they reach the average rotation in their sector. The route to take is to strengthen policies that favor the optimization of margins that, together with the normal levels of rotation in the sector, will strengthen economic profitability.

Margin can be considered as the main determiner of profitability and it has a greater influence on medium- and large-sized companies than on small businesses and microenterprises. However, assets turnover has a greater impact on smaller companies, because they are more intensive in terms of rotations than large companies, since they are capable of obtaining a greater margin (Sánchez \& García., 2003).

Asset turnover must be considered one of the most important variables for improving or jeopardizing economic profitability, and therefore a decrease in sales has a direct impact on the ROI, resulting in a decrease in margin. The reduction in asset turnover affects a hotel establishment in terms of its investments and sales volume (Martorell \& Mulet, 2009).

\subsubsection{Operating leverage}

First we will define what we understand by operating leverage or leverage effect, that is obtained in a certain area of the company under certain economic circumstances.

When a company suffers a reduction of $25 \%$ in its sales, for example, this can be translated into a decrease in operating benefits of $300 \%$. This decrease, more than a proportion of the operating profits in relation to a determining decrease in sales, is explained by the leverage effect exercised by the fixed costs. This effect is called operating leverage, which obviously occurs in both directions. Operating leverage arises when there are fixed costs in the cost structure of the company and it is defined as a percent variation of the operating profits (EBIT), as the result of a certain percent variation in sales. Expressed differently, it would be the percentage of variation in EBIT with a certain variation in the number of units sold (Mascareñas, 2001). 
When the fixed expenses are substantial, a higher level of activity for a certain structure will tend to increase the profit margin, since within certain activity margins, the costs increase proportionally less than the sales (Vázquez, 2001).

Modifications in activity will change the company's results, not only due to the increase or decrease in the units sold or the effect of the change in the commercial mix, but also because they will trigger, along with the evolution of the total fixed costs, an increase/decrease in the per unit fixed costs, and this is the real reason for the existence of operating leverage. Whether the company is operationally leveraged makes it possible to assess the impact of the fixed costs on the variation in the business results (Aranda \& Diéguez, 2006).

In our case, the hotel sector, this has a significant effect on us and it must be considered that any variation in the EBIT has a direct impact on economic profitability. The hotel sector has a cost structure that must support numerous fixed costs and its becomes essential to know the so-called break-even point or profitability threshold, and thus each hotel must determine the level of sales after which the company starts to generate profits. This is done through the study of the relationships between the cost structure, sales volume and company's profit (Mascareñas, 2001). In terms of the cost behavior in hotel establishments, we can point out that fixed costs, such as salaries, the amortization of buildings and facilities, among others, are very high as compared to variable costs. Fixed costs are considered to be those costs that do not vary over the short term in light of changes in the hotel's occupancy rate (Amat \& Campa, 2011).

\subsubsection{Management system}

As described by Amat and Campa (2011), there are different types of management of hotel establishments, depending on the type of property:

- Management contract. This is an agreement between the company that owns the hotel and a hotel management company for the latter to operate the hotel.

- Leasing contract. This is an agreement between the owner and a management organization for the lease of a hotel business, and not just the establishment with all the facilities, properties and furnishings.

- Franchise contract: This is a cooperation agreement between the management company (franchiser) and the franchisee (which may or may not be the hotel owner) in which the former transfers to the latter the right to market certain services and products in exchange for economic compensation.

- Affiliation with a hotel group: This type of agreement provides access to a reservations center and commercial structure, among other advantages, to certain independent hotels of a certain size that do not have the possibility of possessing an equivalent structure at a reasonable cost.

- Own management: This is the case of a company that owns a hotel that decides to manage it directly, without any operators or managers.

The Spanish hotel market structure is characterized by a low level of concentration. This peculiarity implies a wide variety of ownership and management models of hotel establishments, and no claim can be made that any one model is better than any other. The choice of options will depend on the interests of the owner-investor and his capacity to take risks. The analysis of the location of each hotel establishment, its structure and the different interests of the property will dictate which model is recommendable (Casamitjana, 2008).

The relevance of the selection of an appropriate organizational model contributes to the improvement of the company's economic results. The largest hotels tend to be private property, in whole or in part, while the smallest ones tend to be rented, managed or franchised. The brand's interest in maintaining a strict control over its most emblematic hotels and/or the difficulty to find investors with enough resources (both financial, due to the size of the investment, and in terms of knowledge, due to the difficulty of operating a large hotel) favor the integration of large establishments. This is based on the idea that the assignment of ownership rights offered by each organizational mechanism generates different degrees of control by the hotel company over the keys assets 
for the service production. Hotel companies choose the organizational formula that responds best to the contractual risks derived from obtaining the usage rights of the production factors necessary to offer the hotel service. Therefore, the specificity of the assets, the control costs for each establishment, the coordination costs and the difficulty to transfer resources and capacities to manage large hotels and offer high-quality services will affect the choice of the organizational model of each establishment (Fernández \& González, 2008).

Larger organizations are usually directly operated (as private property) by the brands, which is well-justified by the importance that these more emblematic establishments offer a good image, or the difficulty to find owners or operators in the market with the knowledge necessary to successfully manage this type of business or even to make the required investment (Brickley \& Dark, 1987; Milgrom \& Roberts, 1992; Holmström \& Milgrom, 1994; Holmström, 1999; Kehoe, 1996; Calderón, 2002; Ramón, 2002b; Plan \& León, 2004). In 2003, private investors dominated the ownership of three- to five-star hotels in the USA at levels of $81 \%$, in Europe at levels of $79 \%$ and in Australia at levels of 78\% (Newell \& Seabrook, 2006).

\subsubsection{Quality management system}

The authors Tari and Pereira (2012) state that only $8 \%$ of hotels are certified and they believe that it is necessary to urgently incorporate quality management systems in the sector. One way of developing the quality culture is through the standards ISO 9001 or UNE 182001. The standard ISO 9001 is an international quality management standard that can be applied to any company in the world, regardless of its size or sector. This standard defines quality management as a set of coordinated activities to lead and control an organization in terms of quality. It generally includes the establishment of a quality policy and quality objectives, as well as the planning, control, assurance and improvement of quality. The quality management system is that part of the management system focused on leading and controlling an organization in relation to quality. The standard UNE 182001, "Hotels and

tourist apartments. Requirements for the service provision," is a quality standard that can be applied to hotels and tourist apartments and that is also being implemented instead of standard ISO 9001 (Tari \& Pereira, 2012).

If we focus on the hotel sector, even though service quality is a key aspect for hotels (Crick \& Spencer, 2011; Ladhari, 2012), the positive effects of the quality certification in this sector can be the following:

- Positive effects on employees (for example, on staff turnover, enthusiasm, cooperation and communication), on operating factors, on service quality and on customer satisfaction (Nield \& Kozak, 1999; Rubio et al., 2011).

- Improved hotel image (Bird \& Pearson, 1998).

- Improved financial results (Nicolau \& Sellers, 2010; Rubio et al., 2011; Alonso et al., 2012).

All these aspects indicate that certification can improve results, including financial results, in hotel companies. Certified hotel chains obtain better results than uncertified hotels, achieving better results in terms of total sales, income per room and total income (Tari \& Pereira, 2012).

Nicolau and Sellers (2003) state that it has been empirically demonstrated that quality certificates are associated with positive changes. The impact that the publication of the announcement of having earned a quality certificate (ISO 9000) has on the market value of the company is a proven fact; results show that the market positively reacts to the earned certificate, with an increase in the list price of its shares. This result supports the theory that quality-related news has an impact on the expectations of investors. The derived implications on the management of businesses traded on the stock market that consider the use and dissemination of business excellence models imply that if the aim of their managers is to increase the value for their shareholders, and taking into account that these companies must not only offer quality, but also demonstrate it, then certification and subsequent communication of existing quality systems are a good method for achieving this goal. Obtaining a certification implies a new assessment of profitability (Aragón \& Rubio, 2005). 
Companies with quality certification are more efficient in percentages significantly above the average in their respective sectors. Therefore, it can be stated that having this certification explains the greater efficiency of the companies (AECA, 2002).

The quality of the tourist destination depends on endogenous and exogenous factors, but the tourist always evaluates it in a global manner, and thus it is necessary for the set of elements that make up the overall tourist product to be of quality, in other words, it satisfies the tourists. It is a question of improving the quality of the visitor's experience, which not only generates long-term benefits; it also provides greater satisfaction and customer loyalty. Only the quality of the tourist destination, considered as a quality experience by the visitors, will make these destinations profitable in the widest sense, and consequently, make them competitive (Gandara et al., 2007).

If the standard is correctly adopted, it can have positive effects on the following results: financial (increased sales, improved market share), operational (better relations with suppliers, lower costs and fewer non-conformities, meeting of delivery deadlines), customer satisfaction (fewer complaints, improved satisfaction) and employee satisfaction (better health and safety in the workplace, lower absenteeism, increased participation) (Casadesús \& Karapetrovic, 2005).

\subsubsection{Environmental management system}

The European Union's Social Corporate Responsibility Green Book states that correct environmental management has become practically mandatory in any organization that wishes to obtain excellent economic results. Furthermore, society itself demands that companies be respectful of their surrounding environment and those who know how to take advantage of this show the public the improvements that are being made for the environment and the practices they have implemented. To do this, it is essential to be in possession of certifications obtained through independent companies of recognized prestige that accredit the good environmental practices, according to international standards such as ISO 14001 or EMAS (Eco-Management and Audit Scheme) on a European level. In general, the reduced consumption of resources or waste and pollutant emissions can reduce the environmental impact. It can also prove advantageous for companies to reduce their energy and waste-disposal expenditures, also reducing inputs and the costs of decontamination. Different companies have determined that a decrease in consumption of raw materials can result in an increase in profitability and competitiveness (EU CSR Green Book, 2001).

For example, the hotel chain NH (NH Hotels, 2012), in its 2011 annual report edited by investors and shareholders, reveals that in spite of having increased employment by $3.1 \%$, the company has decreased:

- Energy consumption: decreased by $9.9 \% \mathrm{kwh} /$ customer and night.

- Water consumption: decreased by $2.9 \%$ liters/customer and night.

- $\mathrm{CO}_{2}$ emissions: decreased by $11.9 \% \mathrm{~kg} /$ customer and night.

- Waste production: decreased by $10.7 \% \mathrm{~kg} /$ customer and night.

All these reductions have had a direct impact on expense reduction and EBIT improvement, thus increasing the economic profitability in the 2011 financial year.

Companies that have implemented the ISO 14001 standard offer the guarantee that they have annual plans with environmental objectives, that environmental impacts are measured, environmental projects are monitored, the policies of reduce, reuse and recover are applied, etc. All this has a direct repercussion on economic profitability, since measures to reduce electricity, water and fuel consumption, among others, have a direct effect on reducing expenses, which maximizes margins, and therefore, economic profitability (Pereira et al., 2011). With an eye on the future, the quest for profitability in the hotel sector cannot be understood without being accompanied by suitable management of environmental policies (Martorell \& Mulet, 2009). 
Quality and environmental certification can help companies improve their efficiency and results. Some companies earn both certifications and obtain synergies derived from the similarities and parallelisms between the two management systems. It has been shown that a concern for quality and environmental management can improve business performance. This is because these management systems can reduce costs and improve the image of the hotel, which is sure to influence the operational and financial performance, since it has been shown that certified hotels obtain higher performance levels (Molina, Claver, Cortés, Pereira \& Tarí, 2009).

There are important differences between hotels that have adopted the ISO 14001 standard, a proactive tool for environmental management, and those that have not, since it has been demonstrated that environmental certification increases economic results (Segarra et al., 2012).

\subsubsection{Corporate social responsibility}

Corporate social responsibility (hereafter, CSR) is the way companies do business and is characterized by taking into account the impacts that all aspects of their activities have on their customers, employees, shareholders, local communities, the environment and society in general. Companies that voluntarily apply CSR are affected in all aspects related to mandatory compliance with national and international legislation as related to social, labor, environmental and human rights matters, as well as any other voluntary action that the company wishes to undertake to improve the quality of life of its employees, the communities in which they operate and society as a whole (Corporate Social Responsibility Observatory, 2012).

More and more European companies are strengthening their social responsibility strategies in response to different social, environmental and economic pressures. Their aim is to transmit a signal to the agents with whom they interact: employees, shareholders, investors, consumers, public authorities and non-governmental organizations (NGOs). This way of acting becomes an investment in the future and the companies hope that the commitment they have voluntarily accepted contributes to increased profitability.

The financial institutions increasingly turn to social and environmental control lists to assess the risks of loans granted to companies and the investments made. On the same token, the fact that a company is listed as being socially responsible, for example, for having been included in an index of ethical values, can be positively reflected in its share prices and provide financial benefits.

The social indexes of the stock markets constitute useful parameters to show the positive repercussions on the financial results of a selection based on social criteria: since its creation in May 1990, the Domini 400 Social Index (DSI) has exceeded the SP500 by more than 1\% in terms of total annual profitability and risk-adjusted return, while the Dow Jones Sustainable Index has grown 180\% since 1993, as compared to the 125\% growth of the Dow Jones Global Index during the same period (Green Book: Promoting a European Framework for Corporate Social Responsibility, 2001).

It is difficult to precisely evaluate which factors determine the profitability of a socially responsible company. Socially responsible companies are expected to have above-average profits, since their capacity to successfully tackle environmental and social problems can be a credible measure of the quality of their management, which will increase their profitability (Green Book: Promoting a European Framework for Corporate Social Responsibility, 2001).

The CSR strategy, understood as a social strategy, must be directly linked to the mission, vision and values of the company and incorporated into the production chain/service creation and the value chain, as well as into the management of its relations with different groups within the company (Toro, 2006).

Only following this premise of merger between the company's philosophy (how the business is understood) and what is shown to interest groups will it be possible to achieve economic profitability over the medium and long term, but never immediately, since the different agents must be convinced that the company is not taking a series of actions as the result of a speculative interest, but rather because it is the form of action designed and established by the company's management. 
With regard to the company's motivation to adopt CSR policies, this originates in a market demand, which implies that they do not necessarily need to be in conflict with business profitability, but rather quite the opposite. CSR thus consists of adopting a long-term vision of maximizing business profits based to a large extent on maintaining a cooperative strategy with the different company stakeholders (Calveras \& Ganuza, 2008).

When there is a commitment by all the parties interested in the direction of the company and this is reflected in the company's own mission statement, positive financial performance is achieved as a result of the CSR strategy itself. All the financial performance indicators are higher in socially responsible companies, and it is believed that this difference is due to better management, as well as recognition of its activity by customers and, in general, interest groups (Moneva et al., 2007).

\subsubsection{Yield Management}

Yield Management or Revenue Management (hereafter, YM) is understood as it is applied to the hotel sector as the art of selling the right room to the right customer at the right price and at the right time (Smith et al., 1992). This is a business philosophy, according to which there must be a culture of YM within the company and the customers and employees must understand, through adequate information, that the practices that are derived from the application of YM make it possible to obtain maximum profit for both the company and the customer (Talón et al., 2012).

Doing so requires different variables and parameters to be analyzed simultaneously, applying different mathematical and statistical models. The application of YM is intended to channel new marketing formulas through analytic and strategic management that make it possible to optimize the profitability of the hotel (Campa, 2007).

Kimes, as an expert in the air transportation sector, assures that other companies, especially in the service industries, such as lodging, car rental and goods transport, have observed the success of the pricing strategy in the airline industry and have attempted to adapt the concepts of this pricing strategy to their industries. If this airline's definition of the YM were to be extended to other industries, it would be reflected in the pricing per unit of available inventory strategy; for example, the performance of a hotel would be measured as income per available room. While these other industries are certainly not identical, they do have one characteristic in common: fixed capacity (Kimes, 1989).

YM is a strategy that combines capacity management with demand management in service organizations, and is a technique with demonstrated profitability (Chávez \& Ruiz, 2005). In the hotel sector, a service is marketed that has an expiration date, and an unoccupied room means lost income that cannot be recovered. The establishment of the pricing strategy plays a crucial role in hotel YM. The risk of selling at too high of a price could mean not reaching the desired level of employment. Furthermore, the risk of selling at too low of a price means not reaching the desired income level. For this reason, the status of the hotel occupancy must be monitored continuously, in addition to the anticipated reservations, the competition, the advanced notice provided, etc., in order to establish the correct sales price at each particular moment.

Income management consists of maximizing it through efficient management of a perishable asset by determining its price and inventory control. In this sense, it is necessary to define the rooms as a perishable service or product: today is the only opportunity to sell each room; after midnight, the opportunity is lost forever. In the case of the hotel sector, maximization will be obtained from the inventory management of the rooms, by defining a sales strategy based on an analysis of the demand and setting prices based on the positioning of our product with regard to the competition (AECA, 2005).

Talón et al. (2012) describe the characteristics to apply YM:

- Relative fixed capacity. YM is suitable for sectors that have a short-term fixed capacity, such as the case of service companies. 
- Perishable inventory. If a unit is not occupied within a period of time, it is lost and cannot be inventoried.

- High fixed costs and low variable costs. This is the case of the hotel sector, where the fixed costs are very high, but on the other hand, the variable costs are relatively low and permit a certain degree of flexibility in the pricing.

- Possibility of segmenting the sector. This refers to the market division into homogeneous subgroups of customers who demand the same products and react similarly to actions by the marketing-mix.

- Possibility of price differentiation. This is based on distinguishing prices by segments of consumers, charging higher prices to groups of customers who are less sensitive to price changes and lower values to those who are most sensitive.

- Variable demand. Changes in demand can occur according to the time of year, the week, the day and even the time of day.

- Possibility of selling the product ahead of time. In YM, it is crucial for the sale to be able to be made ahead of time, through a reservations system, in which the inventory units are sold for later use.

In terms of the benefits of implementing Yield Management in hotels, there are different estimations. Goymour and Donaghy (1995) say that an increase in rates of between 3.5 and $5 \%$ occurs in the first eleven months, which is the equivalent of 5 to 10 dollars (USD) more per night (Rowe, 1989). When Hilton introduced the system, it reported an increase of 7.50 USD in the average rate without reducing employment during the first month (Orkin, 1988), increases of 3-7\% in income and increased profits by as much as 50\% (Jones, 2000) or increases in income of around 2-5\% (Campa, 2007).

The verification of the economic impact of applying the Yield Management philosophy is very difficult to obtain, because it is complicated to isolate the effect that other factors can have on the results. It is necessary to analyze long time intervals and collect data for at least three years, both before and after the implementation (Jones, 2000). The benefits are both economic (increased profitability) and in terms of management (better information about customers, better decision-making, greater staff motivation, etc.). It has been demonstrated that the higher the level of YM implementation, the better the perception is among those responsible that this philosophy increases the benefits and the knowledge of the market and the product (Talón et al., 2012).

Yield Management techniques and tools actually improve customer management and permit increased percustomer income, but they should have a financial perspective of increased value, preferably based on an analysis of per-customer profitability over the medium and long term. The selection of the most profitable customers must take precedence over the profits of a particular department. Obtaining the maximum profit per customer is more important than maximizing sales with these customers (Talón et al., 2012).

Real data have been presented in favor of Yield Management, showing the profits earned by some companies that apply the technique in relation to the aviation and hotel sectors:

- Smith et al., 1992: "According to estimates by American Airlines, a measurable profit of 1.4 billion USD has been earned over three years (1989-1991), and it is expected to contribute around 500 million dollars in the future."

- Cook, 1998: "We estimate that the Yield Management system at American Airlines generates an increased annual performance of nearly 1 billion USD."

- Lieberman, 1993: "The Marriot International hotel chain experienced an increase in profits in 1991 of around 25-35 million USD. Meanwhile, the car rental company Hertz increased its profits by 1-5\% annually." 
Yield Management emerged from American companies in the 1970s as a way to obtain long-term sustainable competitive advantages. The intent was to manage capacities in order to maximize the overall income of service companies, selling each product or service at the best price to the right customer and at the most appropriate time of the year. Other sectors soon incorporated it and its use was gradually adapted to each specific problem area. During the 1990s, Spanish companies, particularly those in the tourism sector, put it into practice and introduced it as an innovation in their management. Meanwhile, in the United States, Yield Management was in its demystification phase, and was expanded by other new management systems (González \& Sule, 1994).

\subsubsection{Longevity}

To define this factor, we will first say that longevity is a continuous period of time during which a company has performed an economic activity. According to Brüderl and Schüssler (1990), longevity is considered if a company surpasses its fifth year of life, a period in which it must firmly establish itself and mature enough to remain active in the market. These same authors also state that the probability of failure does not reach its maximum values at the start of a company's life, since it can survive for a certain amount of time by using the assets it was founded with; it is after the 5-year mark when companies that do not fail can survive and after 15 years, this number diminishes. The impact of longevity occurs in the groups of small and very small companies, more so than in medium-sized and large enterprises (Sánchez \& García, 2003).

The selection criterion of establishing the five-year mark was determined after verifying that the only clear reference with data found in the literature review is that shown in Table 4. Until the fourth year, both small and large companies have a survival percentage greater than $50 \%$. After the fifth year, small businesses drop below this threshold (Taymaz \& Köksal, 2006). These values should therefore be studied with companies in the hotel sector to substantiate these data.

\begin{tabular}{|c|r|r|}
\hline Age (years) & Small companies & \multicolumn{1}{c|}{ Large companies } \\
\hline 0 & $100 \%$ & $100 \%$ \\
\hline 1 & $78.4 \%$ & $85.7 \%$ \\
\hline 2 & $66.2 \%$ & $75.4 \%$ \\
\hline 3 & $57.6 \%$ & $68.9 \%$ \\
\hline 4 & $50.8 \%$ & $62.9 \%$ \\
\hline 5 & $42.9 \%$ & $57.4 \%$ \\
\hline 6 & $36.6 \%$ & $51.8 \%$ \\
\hline 7 & $32.7 \%$ & $49.6 \%$ \\
\hline
\end{tabular}

Table 4. Survival percentage of small and large companies in the textile sector in Turkey

(Taymaz \& Köksal, 2006)

The creation of a new company is an activity with a great probability of ending in failure. For this reason, only $32.7 \%$ of small companies and $49.6 \%$ of large companies survive beyond 7 years.

To substantiate the data provided by Taymaz and Köksal (2006), it is necessary to also study the mortality rate of companies or winding up of business activities (dissolution of the combination of production factors) and the percentage of companies that maintain their activity over time. In our case, we are interested in knowing the survival rate of the companies. In this regard, the European Union, through Regulation Commission number 2700/98, establishes that the survival rate is calculated as the maximum over a period of three years (López \& Vázquez, 2007).

With everything that has been described, we can state that there is a direct relationship with profitability and it primarily affects small and very small companies, since they have lower economic profitability levels than medium-sized and large companies with greater longevity (Sánchez \& García, 2003). 


\subsubsection{Location and position}

Location or position is a factor with a great impact on the hotel sector, because the decision regarding where to build a hotel requires certain nearby tourism resources. It is the strategy defined by the company that will decide whether we locate our business on the beach, in mountain areas to take advantage of the snow, in cities with historical attributes, such as monuments, or in important cities, near airports, ports, etc. The location economies arise when the companies are geographically concentrated, because they require a specific factor located in a specific geographic area or because they share suppliers and markets (Pereira et al., 2011).

In order to conduct any type of study of this factor, it is necessary to bear in mind that the best classification for segmenting the hotel sector in Spain is to divide the hotels into three groups: urban, beach and rural (Smolyaninova, 2007). This will enable us to differentiate among the three most common destinations in our country: urban tourism, leisure travel or business travel, the most stable throughout the year, beach tourism, which is basically a more seasonal form of leisure tourism, and finally, rural tourism, which is also seasonal, but very sensitive to the current economic situation.

We can show the location as an intangible value that will be reflected, if correctly chosen, in an increase in the economic performance of the hotel. Roubi (2004) states that this factor will not be the same if the hotel is in a city, if it has a highway nearby or if the airport is close by, although in my opinion, this statement must be accompanied by real data in order to verify this allegation.

\section{Discussion of the results}

\subsection{Gaps identified}

From the review of the literature, the first gap we can identify is that no documents have been found that would tell us about the impact of longevity on a business in the hotel sector. This shortcoming does not allow us to know where the barrier is which is the basis to say that the profitability of the hotel will be greater or lesser, taking into account this longevity.

The second gap refers to the fact that no studies were found to assess the impact of corporate social responsibility as a global aspect in the hotel sector as a whole, i.e., taking into account the impacts that all the aspects of its activities have on its customers, employees, shareholders, local communities, the environment and society in general. The only reference found in Scopus that mentions CSR is by Dinu and Nistorescu (2015), but at no time does it take into account the entire concept of RSC, which it only partially considers.

\subsection{Future lines of research}

From the gaps identified and the texts reviewed, a number of lines of research are revealed that could surely result in future studies that will enable us to identify and find out more about the factors that were considered in this study on the hotel sector.

As future lines of research, first of all, it is proposed to study how the longevity and type of property/management of the hotels impacts profitability.

Secondly, it is proposed to conduct an empirical study to assess the incidence of corporate social responsibility on profitability in hotels, researching to verify in greater depth the relationship between social strategies and economic strategies. Social strategies are understood to be anything related to the mandatory compliance with national and international legislation in aspects related to social, labor, environmental and human rights matters, as well as any other voluntary action that the company wishes to undertake to improve the quality of life of its employees, the communities in which it operates and society as a whole (Corporate Social Responsibility Observatory, 2012).

Thirdly, the relationship between the size of the company and its profitability should be analyzed, comparing different countries in the European Union. 
Fourthly, studies should consider the influence of the location and position of the hotel, considering urban, beach and rural hotels. We propose a study to calculate the effect of location by using different levels of territorial aggregation or location variables, such as Autonomous Communities, provinces or important tourist destinations.

Fifthly and finally, a longitudinal study should be conducted using large databases, such as SABI and a wide variety of the previously mentioned factors to define which of these have the most influence on the results of hotel companies.

\section{Conclusions}

The first conclusion of the study presented is that there are factors proven to be key to success in the hotel sector. Many of these factors are common to all business organizations.

The second conclusion is that there is a need to find out more about these factors in order to know the relationship they might have with profitability in the hotel sector. It becomes crucial to be able to demonstrate that a hotel company has a higher economic profitability as the result of having complied with a series of requirements (factors) that others do not have, which obligates us to demonstrate that the combination of these eleven key success factors, or some part of them, has a direct impact on said profitability of the hotel companies. In the case that this relationship is demonstrated, we will be contributing to the scientific community greater economic knowledge about the hotel sector.

The third conclusion is that this study opens the door to different research lines, as described above. But it should be stressed that conducting a longitudinal study of the most representative factors of the hotel sector, such as its location and position, the ownership/management systems, and quality and environmental management systems will make it possible to determine a profile of hotel companies and, according to their profitability, we will be able to establish different categories.

Finally, and in conclusion, identifying those factors that would enable us to predict their future evolution would make it possible to define how the current level of profitability could be reproduced in the next or upcoming periods, ensuring the survival of the hotel company in the future.

\section{Declaration of Conflicting Interests}

The authors declared no potential conflicts of interest with respect to the research, authorship, and/or publication of this article.

\section{Funding}

The authors received no financial support for the research, authorship, and/or publication of this article.

\section{References}

Abdel-Maksoud, A., Kamel, H., \& Elbanna, S. (2016). Investigating relationships between stakeholders' pressure, eco-control systems and hotel performance. International Journal Of Hospitality Management, 59, 95-104. https://doi.org/10.1016/j.ijhm.2016.09.006

Acedo, M.A., Ayala, J.C., \& Rodríguez, J.E. (2005). Rentabilidades, endeudamiento y coste de la deuda de las pymes: Análisis empírico de las empresas por tamaños. Revista Europea De Dirección y Economía De La Empresa, 14(4), 185-99.

Acero, I., \& Nuria, F. (2012). Gobierno corporativo y rendición de cuentas: ¿Existe algún efecto sobre la performance empresarial?. Revista De Contabilidad, 15(1), 143-178. https://doi.org/10.1016/S1138-4891(12)700419

AECA (2002). Factores determinantes de la eficiencia y rentabilidad de las Pyme en España. 
AECA (2005). La contabilidad de gestión en las empresas hoteleras, Asociación Española de Contabilidad y Administración de Empresas.

Álvarez, A., Andrade, M., Caramés, R., Gomis, A., Leira, J., \& Rego, G. (2008). Innovación turística: Perspectivas teóricas y objetos de estudio. ROTUR. Revista De Ocio y Turismo, 35(1), 19-50.

Alonso, M.M., Rodríguez, J.M., \& Rubio, L. (2012). Reasons for implementing certified quality systems and impact on performance: An analysis of the hotel industry. The Service Industries Journal, 32, 919-936. https://doi.org/10.1080/02642069.2010.545886

Amat, O., \& Campa, F. (2011). Contabilidad, control de gestión y finanzas de hoteles. Barcelona: Profit.

Andrés, J. (2000). Caracterización económico-financiera de las empresas asturianas en función de su nivel de rentabilidad. Revista Asturiana De Economia, 18, 191-222.

Andreu, R., Claver, E., \& Quer, D. (2017). Firm-specific factors and entry mode choice: An analysis of Chinese hotel chains. Tourism Economics, 23(4), 756-767. https://doi.org/10.5367/te.2016.0557

Antón, C., Cuadrado, C., \& Rodríguez, J.A. (1990). Factores explicativos del crecimiento y la rentabilidad. Investigaciones Económicas. Suplementos, 24, 153-158.

Aragón, A., \& Rubio, A. (2005). Factores asociados con el éxito competitivo de las Pyme industriales en España. Universia Business Review, 8, 38-51.

Aranda, E., \& Diéguez, J. (2006). Un análisis del apalancamiento operativo y su relación con el resultado empresarial. Revista Iberoamericana de Contabilidad de Gestión, 7, 47-80.

Aras, G., Aybars, A., \& Kutlu, O. (2010). Managing corporate performance: Investigating the relationship between corporate social responsibility and financial performance in emerging markets. International Journal of Productivity and Performance Management, 59(3), 229-254. https://doi.org/10.1108/17410401011023573

Arbelo-Perez, M., Arbelo, A., \& Perez-Gomez, P. (2017). Impact of quality on estimations of hotel efficiency. Tourism Management, 61, 200-208. https://doi.org/10.1016/j.tourman.2017.02.011

Arraiza, C., \& Lafuente, A. (1984). Caracterización de la gran empresa industrial española según su rentabilidad. Información Comercial Española. Revista De Economia, 611, 127-139.

Barnett, M., \& Salomon, R. (2006). Beyond dichotomy: The curvilinear relationship between social responsibility and financial performance. Strategic Management Journal, 27, 1101-1122. https://doi.org/10.1002/smj.557

Barrado, D.A., \& Galiana, L. (2006). Ideas y modelos de planificación territorial en los orígenes del turismo de masas español: La ley de centros y zonas de interés turístico nacional frente a la ley del suelo. Estudios Turísticos, 167, 7-36.

Ben Aissa, S., \& Goaied, M. (2016). Determinants of tourism hotel market efficiency. International Journal of Culture, Tourism, and Hospitality Research, 10(2), 173-190. https://doi.org/10.1108/IJCTHR-11-2013-0080

Benavides-Velasco, C.A., Quintana-Garcia, C., \& Marchante-Lara, M. (2014). Total quality management, corporate social responsibility and performance in the hotel industry. International Journal of Hospitality Management, 41, 77-87. https://doi.org/10.1016/j.ijhm.2014.05.003

Berges, A., \& Soria, P. (1987). Tamaño, concentración y rentabilidad de las empresas industriales (España y Europa). Economía Industrial, 257, 95-103.

Birdir, K., \& Pearson, T.E. (1998). Hospitality certification: Experiences in North America -international implications. International Journal of Contemporary Hospitality Management, 10, 116-121. https://doi.org/10.1108/09596119810210369

Brickley, J.A., \& Dark, F.H. (1987). The choice of organizational form: The case of franchising. Journal of Financial Economics, 18(2), 401-420. https://doi.org/10.1016/0304-405X(87)90046-8 
Brüderl, J., \& Schüssler, R. (1990). Organizational mortality: The liability of newness and adolescence. Administrative Science Quarterly, 35, 530-547. https://doi.org/10.2307/2393316

Bueno, E., \& Lamothe, P. (1983). Tamaño y rentabilidad de la gran empresa española: Un análisis empirico de su relación basado en un método multicriterio. Universidad Autónoma de Madrid.

Calderón, M.A. (2002). Factores determinantes de la decisión de franquiciar en las enseñas españolas. Cuadernos de Economía y Dirección de la Empresa, 11, 105-125.

Callado, F., \& Utrero, N. (2005). El impacto de la responsabilidad social corporativa en el valor de mercado de la empresa: Un análisis para el mercado español. Retrieved from: http://www.webmeets.com/files/papers/SAE/2005/264/GOBCORP2.pdf

Calveras, A., \& Ganuza, J.J. (2008). Responsabilidad social corporativa. Una visión desde la teoría económica. Cuadernos Económicos de ICE, 76, 101-18.

Calvo, A., García, D., \& Arques, A. (2000). Posición del riesgo financiero en la industria española. Decisiones Financieras y Fracaso Empresarial. Madrid: AECA.

Campa, F. (2007). La contabilidad de gestión en la industria hotelera: Estudio sobre su implantación en las cadenas hoteleras en España. Universitat Rovira i Virgili. Departament de Gestió d'Empreses.

Carvell, S.A., Canina, L., \& Sturman, M.C. (2015). A Comparison of the Performance of Brand-Affiliated and Unaffiliated Hotel Properties. Cornell Hospitality Quarterly, 57(2), 193-201. https://doi.org/10.1177/1938965516631014

Casadesús, M., \& Karapetrovic, S. (2005). Has ISO 9000 lost some of its luster? A longitudinal impact study. International Journal of Operations \& Production Management, 25, 580-596.

Casamitjana, C. (2008). Modelos de estructura de propiedad y de gestión en el sector hotelero. Harvard-Deusto Finanzas y Contabilidad, 86, 56-63.

Castelltort, M. (2006). La rentabilidad del turismo español: ¿Problema de producto o de demanda?: El caso de suiza. Estudios Turísticos, 167, 55-90.

Caves, R. (1974). Causes of direct investment: Foreign firms shares in Canadian and United Kingdom manufacturing industries. Review of Economics and Statistics, 56, 279-293. https://doi.org/10.2307/1923965

Cetin, G., Demirciftci, T., \& Bilgihan, A. (2016). Meeting revenue management challenges: Knowledge, skills and abilities. International Journal of Hospitality Management, 57, 132-142. https://doi.org/10.1016/j.ijhm.2016.06.008

Chávez, M.E., \& Ruíz, A. (2005). Marco conceptual del yield management como técnica de gestión de la capacidad y la demanda en organizaciones de servicios. Investigaciones Europeas de Dirección y Economía de la Empresa, 11(1), 143-163.

Cheng, X., Liao, S.S., Xu, Y., Hua, Z., \& Dai, Y.E. (2015). Contagion in a Financial System. International Conference on Information Systems Development, International Conference on Information Systems Development, China. Code 119997.

Chow, C., Goh, M., \& Wan, T.B. (2003). Does ISO 9000 certification improve business performance? International Journal of Quality \& Reliability Management, 20, 936-953. https://doi.org/10.1108/02656710310493643

Claver, E., Pereira, J., Molina, J.F., \& Tarí, J.J. (2010). Certificación en calidad y medio ambiente y su relación con el rendimiento empresarial. Papers de Turisme, 47-48, 24-37.

Cook, T.M. (1998). Sabre soars. ORMS Today, 25(3), 26-35.

Corporate Social Responsibility Observatory. Retrieved from: http://www.observatoriorsc.org (Accessed Jult $3^{\text {rd }}$, 2012).

Crick, A.P., \& Spencer, A. (2011). Hospitality quality: New directions and new challenges. International Journal of Contemporary Hospitality Management, 23, 463-478. https://doi.org/10.1108/09596111111129986 
De Jorge, J., \& Suárez, C. (2014). Productivity, efficiency and its determinant factors in hotels. Service Industries Journal, 34(4), 354-372. https://doi.org/10.1080/02642069.2013.778977

Dinu, A., \& Nistorescu, T. (2015). Strategic approaches concerning the sustainable development of the tourism destination Clisura Dunarii. Quality - Access to Success, 16, 473-480.

Donsimoni, M., \& Leoz, V. (1980). Profitability and international linkages in the Spanish industry. Universidad Católica de Lovaina, Instituto de Ciencias Económicas (8.003).

Fariñas, J.C., Calvo, J.L., Jaumandreu, J., Lorenzo, M.J., Huergo, E., De La Iglesia, C. et al. (1992). La PYME industrial en España. Civitas: IMPI.

Fernández, M.A., \& Gil, A.M. (1995). Correlación de magnitudes económicas financieras en base a la dimensión. Actualidad Financiera, 46, 1773-1863.

Fernández, M., \& González, M. (2006). Elección de la forma organizativa en las cadenas hoteleras: El caso de Sol Meliá. Papers De Turisme, 39, 24-43.

Fernández, M., \& González, M. (2008). ¿Cómo organizar una cadena hotelera?: La elección de la forma de gobierno. Cuadernos de Economia y Dirección de la Empresa, 37, 67-95. https://doi.org/10.1016/S11385758(08)70069-0

Ferruz, L., \& Gonzalez, J. (1994). Tamaño y rentabilidad de la banca extranjera en España: 1986-1990. Actualidad Financiera, 46, 655-672.

Figuerola, M. (2011). Contribución del Turismo al PIB. Retrieved from: http://comunidad.hosteltur.com (Accessed June $\left.29^{\text {th }}, 2012\right)$.

Friedman, M. (1970). The social responsibility of business is to increase its profits. New York Times Magazine, 13, 122-126.

Galán, J.L., \& Vecino, J. (1997). Las fuentes de rentabilidad de las empresas. Revista Europea de Dirección y Economía de la Empresa, 6(1), 21-36.

Galvé, C., \& Salas, V. (1993). Propiedad y resultados de la gran empresa española. Investigaciones Económicas, 17(2), 207-38.

Gandara, J.M.G., Fraiz, J.A., \& Alén, M.E. (2007). Hoteles sostenibles para destinos sostenibles. La calidad hotelera como instrumento para la sostenibilidad. XIX Congreso Anual y XV Congreso Hispano Francés de AEDEM.

García, J. (1976). Organización industrial española, 1960-1970. Cuadernos de economia, 4(11), 488-504.

García, F.J., \& Yaiza, C.M. (2007). Aproximación a la incidencia de la responsabilidad social-medioambiental en el resultado económico de la empresa hotelera española. Revista Europea De Dirección y Economía De La Empresa, 16(1), 47-66.

Garcia, P., \& Del Bosque, I. (2015). Exploring the Antecedents of Hotel Customer Loyalty: A Social Identity Perspective. Journal of Hospitality Marketing \& Management, 24(1), 1-23. https://doi.org/10.1080/19368623.2014.891961

González, A.M., \& Sule, M.A. (1994). Expectativas de la utilización del "YIELD MANAGEMENT" en las empresas turísticas. Estudios Turísticos, 123, 47-70.

González, A.L. (1997). La rentabilidad empresarial: Evaluación empirica de sus factores determinantes. Madrid: Colegio de Registradores de la Propiedad y Mercantiles de España, Centro de Estudios Registrales.

González, A., Correa, A., Hernández, J.I., Hernández, M.C., \& Rodríguez, T. (1998). Rentabilidad y crecimiento: Dimensión espacial. Revista Española de Financiación y Contabilidad, 95, 541-573.

González, J.I., Hernández, M.C., \& Rodríguez, T. (2000). Contribución del tamaño y el sector en la explicación de la rentabilidad empresarial. Revista Española de Financiación y Contabilidad, 29(106), 903-30. 
González, C., \& Jareño, F. (2014). Financial analysis of the main hotel chains of the Spanish tourism sector. Euro-American Association of Economic Development Studies, 14(2), 91-108.

Goymour, D., \& Donaghy, K. (1995). Reserving Judgement. Caterer and Hotelkeeper, 26, 64-65.

Green Book (2001). Fomentar un marc europeu per la responsabilitat social de las empreses. Comissió de les Comunitats Europees.

Guha, P. (2016). Revenue management: the ever changing landscape and the need to innovate. Worldwide Hospitality and Tourism Themes, 8(4), 461-468. https://doi.org/10.1108/WHATT-05-2016-0024

Häversjö, T. (2000). The financial effects of ISO 9000 registration for Danish companies. Managerial Auditing Journal, 15(1-2), 47-52. https://doi.org/10.1108/02686900010304632

Heras, I., Dick, G.P.M., \& Casadesús, M. (2002). ISO 9000 Registration's impact on sales and profitability: A longitudinal analysis of performance before and after accreditation. International Journal of Quality and Reliability Management, 19(6), 774-791. https://doi.org/10.1108/02656710210429618

Hernández, A.B., Campa, F., \& Sánchez, M.V. (2012). Categorizing the Spanish accommodation sector: Does firm size influence economic profitability?. Cornell Hospitality Quarterly, 53(3), 257-264. https://doi.org/10.1177/1938965512445459

Hodari, D., Turner, M.J., \& Sturman, M.C. (2017). How hotel owner-operator goal congruence and GM autonomy influence hotel performance. International Journal of Hospitality Management, 61, 119-128. https://doi.org/10.1016/j.ijhm.2016.11.008

Holmström, B. (1999). The firm as subeconomy. Journal of Law, Economics and Organization, 15(1), 74-102. https://doi.org/10.1093/jleo/15.1.74

Holmström, B., \& Milgrom, P. (1994). The firm as an incentive system. American Economic Review, 84(4), 972-991.

Huergo, E. (1992). Tamaño y rentabilidad en la industria española. Economía Industrial, 284, 41-50.

Illueca, M., \& Pastor, J.M. (1996). Análisis económico financiero de las empresas españolas por tamaños. Economía Industrial, 310, 41-54.

INE. Retrieved from: www.ine.es (Accessed March 15 ${ }^{\text {th }}, 2017$ ).

Ivanova, M., \& Ivanov, S. (2015). Affiliation to hotel chains: Hotels' perspective. Tourism Management Perspectives, 16, 148-162. https://doi.org/10.1016/j.tmp.2015.08.001

Jensen, M. (2002). Value maximization, stakeholder theory, and the corporate objective function. Business Ethics Quarterly, 12, 235-256. https://doi.org/10.2307/3857812

Jones, P. (2000). Defining yield management and measuring its impact on botel performance. Yield Management: Strategies for the Service Industries ( $\left.2^{\mathrm{a}} \mathrm{ed}.\right)(\mathrm{pp} .85-97)$. London: Continuum.

Kalnins, A. (2016). Beyond Manhattan: Localized competition and organizational failure in urban hotel markets throughout the United States, 2000-2014. Strategic Management Journal, 37(11), 2235-2253.

https://doi.org/10.1002/smj.2578

Kasim, A., Dzakiria, H., \& Ahmad, R. (2016). Does Firm Size Influence Innovative Water Management Responses in the Hotel Sector? Conference on Advanced Research on Business, Management and Humanities (ARBUHUM).

Kehoe, M.R. (1996). Franchising, agency problems and cost of capital. Applied Economics, 28, 1487-1493. https://doi.org/10.1080/000368496327741

Kim, H.L., Rhou, Y., Uysal, M., \& Kwon, N. (2017). An examination of the links between corporate social responsibility (CSR) and its internal consequences. International Journal of Hospitality Management, 61, 26-34. https://doi.org/10.1016/j.ijhm.2016.10.011 
Kimes, S.E. (1989). The Basic of Yield Management. Cornell Hotel and Restaurant Adminitration Quartely, 30(3), 14-19. https://doi.org/10.1177/001088048903000309

Ladhari, R. (2012). The lodging quality index: An independent assessment of validity and dimensions. International Journal of Contemporary Hospitality Management, 24(4), 628-652.

Lafuente, A., \& Salas, V. (1983). La Teoria Económica de la Dirección Estratégica. Información Comercial Española. Revista de Economía, 595, 63-72.

Lafuente, A., Salas, V., \& Perez, R. (1985). Tipos de empresario y de empresa. El caso de las nuevas empresas españolas. Economía Industrial, 246, 139-151.

Lafuente, A., \& Yagüe, M.J. (1989). Ventajas competitivas y tamaño de las empresas: Las pyme. Papeles de Economía Española, 39-40, 165-184.

Lee, P.K.C., To, W.M., \& Yu, B.T.W. (2009). The implementation and performance outcomes of ISO 9000 in service organizations: An empirical taxonomy. International Journal of Quality \& Reliability Management, 26, 646662. https://doi.org/10.1108/02656710910975732

Lee, J.J., Capella, M.L., Taylor, C.R., Luo, M.M., \& Gabler, C.B. (2014). The financial impact of loyalty programs in the hotel industry: A social exchange theory perspective. Journal of Business Research, 67(10), 2139-2146. https://doi.org/10.1016/j.jbusres.2014.04.023

Lee, S.K. (2015). Quality differentiation and conditional spatial price competition among hotels. Tourism Management, 46, 114-122. https://doi.org/10.1016/j.tourman.2014.06.019

Lewis, R.C., \& Shoemaker, S. (1997). Price-sensitivity measurement: A tool for the hospitality industry. Cornell Hospitality Quarterly, 38(2), 44-54. https://doi.org/10.1177/001088049703800223

Lieberman, H. (1993). Debunking the myths of yield management. The Cornell Hotel and Restaurant Administration Quarterly, 34(1-2), 34-41. https://doi.org/10.1177/001088049303400107

Llach, J., Del Mar Alonso-Almeida, M., \& Marti, J. (2016). Effects of quality management on hospitality performance in different contexts. Industrial Management \& Data Systems, 116(5), 1005-1023. https://doi.org/10.1108/IMDS-06-2015-0235

Llorens, J.L. (1992). Nuevos instrumentos financieros para la pyme. Economia Industrial, 284, 85-98.

Lo, C.K.Y., Yeung, A.C.L., \& Cheng, T.C.E. (2011). Meta-standards, financial performance and senior executive compensation in china: An institutional perspective. International Journal of Production Economics, 129, 119-126. https://doi.org/10.1016/j.ijpe.2010.09.011

Lockyer, T.L.G. (2013). The international hotel industry: Sustainable management (pp. 1-202). Binghamton, NY: The Haworth Press.

López, M.A., \& Vázquez, P. (2007). La actividad emprendedora en Europa: El caso de España a través de un análisis cluster. Economía Industrial, 363, 91-101.

Mak, B.L.M. (2011). ISO certification in the tour operator sector. International Journal of Contemporary Hospitality Management, 23, 115-130. https://doi.org/10.1108/09596111111101706

Maravall, F. (1976). Crecimiento, dimensión y concentración de las empresas industriales españolas. Fundación del INI Serie E, 7.

Maravall, F. (1981). La influencia de la dimensión empresarial sobre la eficiencia: Unas notas sobre el funcionamiento de la industria española. Lecturas De Economía Española e Internacional. Ministerio De Economía y Comercio, Secretaria General Técnica, 151-163.

Marchionna, A. (2005). Una visión estratégica sobre el Revenue Management. Espacio ISH y R, 5, 10-17.

Maroto, J.A. (1993). La situación económico-financiera de las empresas españolas y la competitividad. Economía Industrial, 291, 89-106. 
Maroto, J.A. (1996). Estructura financiera y crecimiento de las PYMES. Economía Industrial, 310, 29-40.

Maroto, J.A. (1998). Central de balances del banco de España: Cada vez mejor. Cuadernos de Información Económica, 140-141, 186-199.

Martínez, M., Choi, T.Y., Martínez, J.A., \& Martínez, A.R. (2009). ISO 9000/1994, ISO 9001/2000 and TQM: The performance debate revisited. Journal of Operations Management, 27, 495-51.

https://doi.org/10.1016/j.jom.2009.04.002

Martorell, O., \& Mulet, C. (2009). Análisis y rentabilidad del sector turístico en las islas baleares: Políticas de reflotamiento. Investigaciones Europeas de Dirección y Economía de la Empresa, 15(2), 77-92.

https://doi.org/10.1016/S1135-2523(12)60090-2

Mascareñas, J. (2001). Análisis del apalancamiento. Universidad Complutense de Madrid.

McWilliams, A., \& Siegel, D. (1997). The role of money managers in assessing corporate social responsibility research. Journal of Investing, 6(4), 98-107. https://doi.org/10.3905/joi.1997.408440

Medrado, L., \& Jackson, L.A. (2016). Corporate nonfinancial disclosures: An illuminating look at the corporate social responsibility and sustainability reporting practices of hospitality and tourism firms. Tourism and Hospitality Research, 16(2), 116-132. https://doi.org/10.1177/1467358415600210

Milgrom, P., \& Roberts, J. (1992). Economics, organization and management. Home Wood: Prentice-Hall International Editions.

Ministry of Energy, Tourism and Digital Agenda. Retrieved from: www.minetad.gob.es (Accessed January 31th, 2017).

Mokhtar, M.Z., \& Muda, M.S. (2012). Comparative study on performance measure and attributes between ISO and non-ISO certification companies. International Journal of Business and Management, 7, 185-193.

https://doi.org/10.5539/ijbm.v7n3p185

Molina, J.F., Claver, E., Cortés, P., Pereira, J., \& Tarí, J.J. (2009). Gestión de la calidad y medioambiental y rendimiento empresarial: Un análisis de los hoteles españoles. Revista Europea de Dirección y Economía de la Empresa, 18(2), 63-78.

Molina-Azorin, J.F., Jose Tari, J., \& Pereira-Moliner, J. (2015). The effects of quality and environmental management on competitive advantage: A mixed methods study in the hotel industry. Tourism Management, 50, 41-54. https://doi.org/10.1016/j.tourman.2015.01.008

Moneva, J.M., Rivera, J.M., \& Muñoz, M.J. (2007). The corporate stakeholder commitment and social and financial performance. Industrial Management \& Data Systems, 107(1), 84-102.

https://doi.org/10.1108/02635570710719070

Monterrey, J., \& Sánchez, A. (2011). Persistencia de la rentabilidad. Un estudio de sus factores determinantes. Revista Española de Financiación y Contabilidad, 40(150), 287-317. https://doi.org/10.1080/02102412.2011.10779704

National and Comprehensive Tourism Plan (2012). Plan nacional e integral de turismo (PNIT) 2012-2015. Madrid: Ministerio de Industria, Energía y Turismo.

Newell, G., \& Seabrook, R. (2006). Factors influencing hotel investment decision making. Journal of Property Investment \& Finance, 24(4), 279-294. https://doi.org/10.1108/14635780610674499

NH Hoteles (2012). Avance ventas y resultados 12 meses 2011. Departamento de Relaciones con los Inversores, NH Hoteles. Retrieved from: http://corporate.nh-hoteles.es/upload/files/NH\%20Hoteles Avance\%20Ventas\%20y\%20Resultados \%2012\%20meses\%202011\%281\%29.pdf (Accessed July 12 $2^{\text {th }}, 2012$ )

Nicolau, J.L., \& Sellers, R. (2003). Influencia de la calidad sobre la rentabilidad y la volatilidad. Revista de Economía Aplicada, 11(33), 65-82.

Nicolau, J.L., \& Sellers, R. (2010). The quality of quality awards: Disminishing information asymmetries in a hotel chain. Journal of Business Research, 63, 832-839. https://doi.org/10.1016/j.jbustes.2009.06.009 
Nield, K., \& Kozak, M. (1999). Quality certification in the hospitality industry: Analyzing the benefits of ISO 9000. Cornell Hotel and Restaurant Administration Quarterly, 40, 40-45.

https://doi.org/10.1177/001088049904000215

Ocaña, C., Salas, V., \& Valles, J. (1994). Un analisis empirico de la financiacion de la pequeña y mediana empresa manufacturera española. Boletín Económico del Banco de España.

Orkin, E.B. (1988). Boosting your bottom-line with Yield Management. Cornell Hotel and Restaurant Administration Quarterly, 28(49), 52-56. https://doi.org/10.1177/001088048802800416

Palacín, M.J., \& Ramírez, L.M. (2011). Factores determinantes de la estructura financiera de la PYME andaluza. Revista de Estudios Regionales, (91), 45-69.

Pereira, J., Claver, E., \& Molina, J.F. (2011). Efectos empresa, grupo estratégico y localización en el sector hotelero español. Cuadernos de Economía y Dirección de la Empresa, 14(2), 123-138.

https://doi.org/10.1016/j.cede.2011.02.006

Pla, J., \& León, F. (2004). La internacionalización de la industria hotelera española. Papeles de Economía Española, 102, 193-206.

Plan Nacional E Integral De Turismo (PNIT) 2012-2015. Retrieved from: http://www.tourspain.es/WebApplicationCMS/Docs/PNIT/Plan $\% 20$ Nacional $\% 20 \mathrm{e} \% 20$ Integral $\% 20 \mathrm{de} \% 20$ Turismo $\% 2020122015$ v4.6.pdf (Accessed March 1 ${ }^{\text {st }}, 2017$ ).

Ramón, A.B. (2002a). Un análisis de las dimensiones del paradigma OLI en la internacionalización del sector hotelero español. Información Comercial Española. Revista de Economía, 803, 141-61.

Ramón, A.B. (2002b). Determining factors in entry choice for international expansion. The case of Spanish industry. Tourism Management, 23, 597-607. https://doi.org/10.1016/S0261-5177(02)00024-9

Rodríguez, L. (1989). Rentabilidad económica y crisis industrial. Fundación de las Cajas de Ahorros (FUNCAS).

Roubi, S. (2004). The valuation of intangibles for hotel investments. Property Management, 22(5), 410-423. https://doi.org/10.1108/02637470410570761

Rowe, M. (1989). Yield management. Lodging Hospitality, February, 65-66.

Rubio, L., Alonso, M.M., \& Rodríguez, J. (2011). Motivations and impacts in the firm and stakeholders of quality certification: Evidence from small- and medium-sized service enterprises. Total Quality Management \& Business Excellence, 22, 833-852. https://doi.org/10.1080/14783363.2011.593858

Salas, V. (1994). Economía y financiación de la empresa española según su tamaño. Revista de coyuntura econòmica, 2, $197-212$.

Sánchez, A. (1994). La rentabilidad económica y financiera de la gran empresa española: Análisis de los factores determinantes. Revista Española de Financiación y Contabilidad, 78, 159-79.

Sánchez, J.P., \& Bernabé, M. (2000). Rentabilidad de la empresa española: 1992-1997. IX Encuentro de Profesores Universitarios de Contabilidad. Las Palmas De Gran Canaria.

Sánchez, J.P., \& García, L. (2003). Influencia del tamaño y la antigüedad de la empresa sobre la rentabilidad: Un estudio empírico. Revista de Contabilidad, 6(12), 169-206.

Sánchez-Medina, P.S., Díaz-Pichardo, R., \& Cruz-Bautista, M. (2016). Stakeholder Influence on the Implementation of Environmental Management Practices in the Hotel Industry. International Journal of Tourism Research, 18(4), 387-398. https://doi.org/10.1002/jtr.2056

Segarra, M.V., Peiró, A., Verma, R., \& Miret, L. (2012). Does environmental certification help the economic performance of hotels? Evidence from the Spanish hotel industry. Cornell Hospitality Quarterly, 53(3), 242-256. https://doi.org/10.1177/1938965512446417 
Small, A., \& Graff Zivins, J. (2002). A Modigliani-Miller theory of corporate social responsibility. Working paper. Columbia University.

Smith, B.C., Leimkuhler, J.F., \& Darrow, R.M. (1992). Yield management at American-airlines. Interfaces, 22(1), 8-31. https://doi.org/10.1287/inte.22.1.8

Smolyaninova, J. (2007). Hospitality market opportunities for the business market segment. MA European Tourism Management. Bournemouth, United Kingdom.

Soler, R. (1977). La política económica y el crecimiento de la dimensión de las empresas. Revista de Investigaciones Económicas, 3, 16-31.

Suárez, A. (1977). La rentabilidad y el tamaño de las empresas españolas. Revista: Económicas y Empresariales, (5), 56-63.

Talón, P., González, L., \& Segovia, M. (2012). Yield Revenue Management en el sector hotelero: Estrategias e implantación. Collado Villalba, Madrid: Delta.

Tari, J.J., \& Pereira, J. (2012). Calidad y rentabilidad: Análisis del certificado Q en las cadenas hoteleras. Universia Business Review, 34, 52-67.

Taymaz, E., \& Köksal, M.Y. (2006). El espíritu emprendedor, el tamaño de lanzamiento y la supervivencia de los pequeños empresarios. Ekonomiaz, $62-2^{\circ}$ Cuatrimestre.

Toro, D. (2006). El enfoque estratégico de la responsabilidad social corporativa: Revisión de la literatura académica. Intangible Capital, 2(4), 338-358.

Vacas, C., \& Landeta, M.H. (2009). Aproximación al último medio siglo de turismo en España 1959-2009. Estudios Turísticos, 180, 21-64.

Vázquez, J. (2001). Resultados del actual proceso de cambio en las estructuras de activo y de pasivo empresarial: La complementariedad e interdependencia entre el apalancamiento operativo y el apalancamiento financiero. Investigaciones Europeas de Dirección y Economía de la Empresa, 7(3), 67-90.

Yagüe, M. (1989). Estructura económico-financiera de la empresa industrial española. Economía Industrial, 267, $175-90$.

Yang, Y., Albaity, M., \& Hassan, C.H.B. (2015). Dynamic capital structure in China: Determinants and adjustment speed. Investment Management and Financial Innovations, 12(2), 195-204.

Intangible Capital, 2018 (www.intangiblecapital.org)



Article's contents are provided on an Attribution-Non Commercial 4.0 Creative commons International License. Readers are allowed to copy, distribute and communicate article's contents, provided the author's and Intangible Capital's names are included. It must not be used for commercial purposes. To see the complete license contents, please visit https://creativecommons.org/licenses/by-nc/4.0/. 